\title{
Ecology of Avicennia marina mangals along Gulf of Aqaba, South Sinai, Red Sea
}

\author{
Ali A. Gab-Alla ${ }^{1}$; Ishrak, K. Khafagi ${ }^{2}$; Waleed, M. Morsy ${ }^{3}$ and \\ Moustafa M. Fouda ${ }^{4}$ \\ 1- Biological Sciences Department, Faculty of Science, Um Al-Qura \\ University, Makkah, Kingdom of Saudi Arabia, \\ 2- Botany Department, Faculty of Science, Suez Canal University, \\ Ismailia, Egypt \\ 3- Ashtom El-Gamil Protectorate, PortSaid, Egypt \\ 4- Natural Reserve Section, Egyptian Environmental Affairs Agency, \\ Cairo, Egypt.
}

\begin{abstract}
$\mathrm{T}$ his study was conducted on a naturally growing mangrove population at Ras Mohammed and Nabq protected areas, South Sinai, during the period 20052006. Avicennia marina is the only growing mangrove species in South Sinai. Its structure, litterfall and seedling distribution were investigated. The total area of mangrove stands is 99.1 hectares with $42 \%$ canopy coverage, average tree height is between $1.7-2.6 \mathrm{~m}$, basal area up to $9.2 \mathrm{~m}^{2}$. ha $\mathrm{a}^{-1}$. Ras Mohammed represents the densest stand $\left(428\right.$ stems $\left.^{-1}{ }^{-1}\right)$. An annual litterfall of $2036.7 \mathrm{Kg} \cdot \mathrm{ha}^{-1} \cdot \mathrm{yr}^{-1}$ was recorded at Rowaiseya with a maximum peak during April. Mangroves at Nabq area have well distribution of seedlings over Abu Zabad site and a localized dense aggregation of seedlings in intertidal areas at Monqataa and Gharqana sites with a seedling density up to $1848 \mathrm{ha}^{-1}$.
\end{abstract}

Keywords: Avicennia marina, grey mangrove, litterfall, sediment analysis, seedling density, South Sinai.

\section{INTRODUCTION}

Mangroves are important component of intertidal ecosystem due to their ecological and socio-economic values. They function as nursery habitats for many animals as well as they protect the coral reefs by trapping sediments derived from the land (Semesi, 1998).

Mangroves along Egyptian coasts of Gulf of Aqaba represent the northern latitudinal limits of the Endo-Pacific east African mangroves. Generally, mangroves are species- poor toward the latitudinal limits. Thus, two species only of mangroves are recorded from Egypt with Avicennia marina (Forssk.) Vierh. (Avicenniaceae) the most widespread. Avicennia marina is tolerant to relatively high salinity, low rainfall and temperature conditions. ElMontqataa stand constitutes the natural northernmost limit of this species (FAO, 
2002). A second species Rhizophora mucronata occurs at a few sites in the Red Sea, South of $25^{\circ} \mathrm{N}$. This species requires more humid conditions and is less tolerant to high salinity when compared with Avicennia marina. In Egypt, Rhizophora mucronata occurs at several southern locations close to the Sudanese border (El-Gazzar, 1995; Galal, 1999).

Nowadays, there is increased concern of the possibility of mangrove decreasing trend, due to the increasing human activities at mangrove areas. These activities include direct exploitation, tourism and other land use purposes (GEF, $1998 \mathrm{a}, \mathrm{b}$ ).

The present study aims at studying ecological aspects dealing with structure of mangrove communities at South Sinai including tree height, basal area, density, canopy coverage, diameter at breast height, stand area and seedling density. Also, annual litterfall production of mangroves at protected areas was investigated. Five mangrove stands were investigated for community structure parameters, one at Ras Mohammed and other four stands at Nabq protectorate including Monqataa, Rowaiseya, Abu Zabad, and Gharqana. The above mentioned aims will be integrating and contributing in management of protected areas at South Sinai.

\section{MATERIALS AND METHODS}

A pilot survey was carried out at the beginning of field work in 2005 to describe various mangrove stands (Fig 1) at Monqataa, Rowaiseya, Abu Zabad, Gharqana and Ras Mohammed.

Random belt transects (Fig 2) were established perpendicular to the shoreline traversing the mangrove forest zone from the higher intertidal zone throughout lower intertidal till edge of mangrove stands on the back reef towards the seaward side. The number of transects sampled to study the mangrove stands were 2 transects distributed through each site as shown in Figures $(1 \& 2)$. Along each belt transect, five of $10 \times 10 \mathrm{~m}$ quadrates were selected within the belt transect.

Within each $100 \mathrm{~m}^{2}$ quadrate, all trees $\geq 5.0 \mathrm{~cm}$ diameter at breast height (dbh), were measured. Among the quadrates, several tree parameters were recorded including diameter at breast height $(\mathrm{cm})$, basal area $\left(\mathrm{m}^{2} . \mathrm{ha}^{-1}\right)$, density (No. of stems. ha ${ }^{-1}$ ), tree height (m), stand area (ha) and canopy overage \%. The height and the diameter of trees were measured using a plastic measuring tape and a caliper. The dbh diameter was measured before the primary branching point, and if branching occurred at the land surface or at few centimeters from land surface, each branch is measured separately as an independent tree (Snedaker, 1984). Total stands area was calculated by field track of hand held GPS by walking around all mangrove stands and verified the area by GIS software ArcGis 9.

Sediment samples were collected form various mangrove stands in order to carry out particle size analysis and organic matter content. Twenty samples 
were collected; two within each transect in all five sites by inserting PVC cores into the soil to a maximum depth of $20 \mathrm{~cm}$. In the laboratory, each soil sample was carefully homogenized to remove roots and other large plant debris. For grain size analysis, about $100 \mathrm{~g}$ of the dry soil of each sample was subjected to a series of sieves ranging from 45 to $500 \mu \mathrm{m}$ mesh-size. Then Sediment was separated into four main groups based on grain size. These four size groups are gravel, sand, silt and clay. Sediments larger than $2 \mathrm{~mm}$ are gravel; sediments between $2 \mathrm{~mm}$ and $63 \mu \mathrm{m}$ are sand; between 63 and $4 \mu \mathrm{m}$ are silt and smaller than $4 \mu \mathrm{m}$ is clay. Grain size and percentage composition (\%) of gravel, sand, silt and clay in the sediment samples were determined after ensuring that the dried samples were devoid of clumps of soil before sieving. Grains separated by each sieve were weighed separated in each sample to represent various grain sizes. The grain weights were recorded and then percentages were calculated for gravel, sand, silt and clay in each soil sample.

For total organic matter content, the soil samples were weighed and oven dried to constant weight at $60{ }^{\circ} \mathrm{C}$, then $10 \mathrm{~g}$ of each soil sample was oxidized at $455{ }^{\circ} \mathrm{C}$ in a furnace for $8 \mathrm{~h}$ until only inorganic ash was left. Organic matter content (\%) was calculated as percentage loss on ignition (Brady, 1990).

The measurement of production rates of litter represents one of the major steps in understanding the structure and function of any mangrove forest ecosystem (Snedaker, 1984). Among the five mangrove stands in south Sinai, Rowaiseya stand has been selected to be investigated for litter production. This was because different growth patterns of Avicenna marina trees were well represented in Rowaiseya and for ease of regular monthly access for collection of litterfall traps.

Litterfall was estimated under canopy of Avicenna marina stand of Rowaiseya by catching falling plant materials in litterfall traps, precisely $1 \mathrm{x} 1$ $\mathrm{m}$, constructed from $0.5 \mathrm{~cm}$ plastic mesh lined with shad cloth, fixed with PVC supports, were randomly distributed over two transects across the northern part of the Rowaiseya stand and elevated above high tide limit. A total of 25 litterfall traps were established, sampling a total area of $25 \mathrm{~m}^{2}$, litter was collected from litterfall traps at monthly intervals; the collected plant materials were immediately washed by tap water then dried at $60^{\circ} \mathrm{C}$, till constant weight. The sampling period cover monthly records of litterfall production from January to December 2006. After collection, litterfall were sorted and various plant materials were weighted separately including leaves, stem \& bark, flowers and seeds. Total monthly litterfall was weighed too.

Among three study areas (Figs 1, A, C \& D) restricted random sampling was applied to investigate seedling distribution. Transects were located perpendicular to the shore line with $10 \mathrm{~m}$ intervals between each transect. Random quadrates of $5 \times 5 \mathrm{~m}$ in sparse areas and $1 \times 1 \mathrm{~m}$ in dense area was used. In each quadrate seedling density (number per unit area) were calculated, seedling height, leaf number, stem diameter were recorded. Geographical 
position using handheld GPS - Garmin 12XL was sited in order to calculate the total area of the seedling ground.

\section{Mangrove stands}

\section{RESULTS}

Five mangrove stands were studied from naturally growing mangrove population at Ras Mohammed and Nabq protected areas along Gulf of Aqaba, South Sinai, during the period 2005-2006 (Figures 1-3).

\section{Monqataa stand}

Monqataa mangrove stand represents the most northern mangrove stand in the western Indo-Pacific region and is located at latitude $28.206397^{\circ} \mathrm{N}$ and longitude $34.420480^{\circ} \mathrm{E}$. The mangrove trees are well developed around a crescent shaped lagoon, and extend to up to $800 \mathrm{~m}$ along the coastline. The whole stand is separated from the sea water by a strip of fossilized reef ranging between 5 and $7 \mathrm{~m}$ in width. The main mangrove lagoon is surrounded by mangrove vegetation.

Monqataa seedling ground located out of the Monqataa mangrove stand. It starts near the mangrove stand and extends directly to the south, big flat back reef substrate is consists from sand and silt sediments.

\section{Rowaiseya stand}

Rowaiseya mangrove is the largest mangrove stand in Nabq protectorate extending continuously for approximately $4.8 \mathrm{Km}$ along the shoreline (Fig 1, B). It is located at latitude $28.179887^{\circ} \mathrm{N}$ and longitude $34.445295^{\circ} \mathrm{E}$. The mangrove stand at this area is quite wide, spread on the shoreline and extend seaward for $480 \mathrm{~m}$. The mangrove trees at Rowaiseya are well developed and form dense vegetation. However, some patches of dwarf mangrove trees also occur in the higher intertidal zone. A large subtidal mangrove lagoon cover about 2.3 hectares is located at the northern portion of the stand. The lagoon is totally surrounded by trees and its depth varies between $0.2-2 \mathrm{~m}$.

\section{Abu Zabad stand}

The mangrove stand located at latitude $28.150751^{\circ} \mathrm{N}$ and longitude $34.448540^{\circ} \mathrm{E}$. At Marsa Abu Zabad the mangrove stand extends for about 1.5 $\mathrm{Km}$ parallel to the shoreline. Its total area is estimated by 14 hectares with different growth levels ranging between saplings, small shrubs, dwarf trees and large well developed trees. The southern margin of the stand occurs as a single line of trees confronting the shoreline. The structural development of Abu Zabad mangrove stand is relatively dense forming a discontinuous strip that occurs parallel to the shoreline and is intercepted by a wide trees free zone with dense aerial roots and many seedlings and saplings at different growth rates. Many dwarf trees occur at the high tide line and some others extend landward forming sand dunes more than $150 \mathrm{~m}$ inland. Abu Zabad seedling ground located within the mangrove stand as a narrow strip with width of $60 \mathrm{~m}$. 


\section{Gharqana stand}

Gharqana mangrove stand is located at latitude $28.119947^{\circ} \mathrm{N}$ and longitude $34.442509^{\circ} \mathrm{E}$ and is adjacent to Gharqana fishermen village. The total area cover of the stand is estimated by 4.5 hectares. This consists of two parts, together forming a stretch surrounding a semi-circular lagoon ranging in depth between $1.5 \mathrm{~m}$ and $2.5 \mathrm{~m}$. Other mangrove shrubs were scattered and forming sand dunes and occasionally occurring in a shared halophytic community with shrubs of Netraria retusa plant close to the shoreline, and extending to about $50 \mathrm{~m}$ inland. The inland growing mangroves extend for about $1 \mathrm{Km}$ parallel to the shoreline to the south of Gharqana lagoon. The soil of mangrove is dominated by sand and mud.

Gharqana seedling ground located southern the Gharqana mangrove stand extends near the lagoon boundary directly, wide flat intertidal back reef substrate consists from sand, few mature pushes grow in this zone.

\section{Ras Mohammed stand}

It is located at latitude $27.727439^{\circ} \mathrm{N}$ and longitude $34.247299^{\circ} \mathrm{E}$ with a small stand of Avicennia marina occupies the narrow fault line at Ras Mohammed extending for approximately $1 \mathrm{Km}$ along the fault line, which has been filled with sand having dense mangrove branching

\section{Mangrove structure}

Results on variation in the structure of Avicennia marina stands in Nabq and Ras Mohammed are represented in Table (1). The average tree height in Ras Mohammed varied between 0.5 and $4.5 \mathrm{~m}$, in Gharqana $(0.5-4 \mathrm{~m})$, Abu Zabad $(0.5-5.5 \mathrm{~m})$, Rowaiseya $(0.5-7.8 \mathrm{~m})$ and in Monqataa $(0.5-6.8 \mathrm{~m})$. The highest trees $7.8 \mathrm{~m}$ were recorded in Rowaiseya. The highest mean tree height $2.63 \mathrm{~m}$ was recorded in Monqataa ( $\mathrm{SE} \pm 1.88$ ), while the lowest tree height $1.7 \mathrm{~m}$ was recorded in Abu Zabad (SE \pm 1.31 ) (Fig 2).

Table (1) lists the highest average diameter at breast height (dbh) that recorded in Monqataa $13.1 \mathrm{~cm}(\mathrm{SE} \pm 2.1)$ while the lowest was in Abu Zabad 7.6 $\mathrm{cm}(\mathrm{SE} \pm 1.2)$. At Abu Zabad the canopy coverage was the lowest $25.25 \%$, while the highest canopy coverage was recorded at Gharqana $56.93 \%$. Ras Mohammed has the most dense mangrove stand 428 stems ha $^{-1}$, while Monqataa $\&$ Rowaiseya show density values of 373,353 stems.ha $^{-1}$ respectively. Abu Zabad has the least dense mangrove 216 stems.ha $^{-1}$ (Table 1).

The total area of mangrove stand at Ras Mohammed was 2.63 ha, Gharqana 0.29 ha, Abu Zabad 28.57 ha, Monqataa 13.95 ha and the largest mangrove in South Sinai located in Rowaiseya with an area of 53.67 ha. Data of basal area varied among the sites, with highest basal area recorded in Monqataa $9.2 \mathrm{~m}^{2} \cdot \mathrm{ha}^{-1}$, while Rowaiseya and Ras Mohammed have basal area of $7.9,7.3$ $\mathrm{m}^{2} \cdot \mathrm{ha}^{-1}$ respectively. 

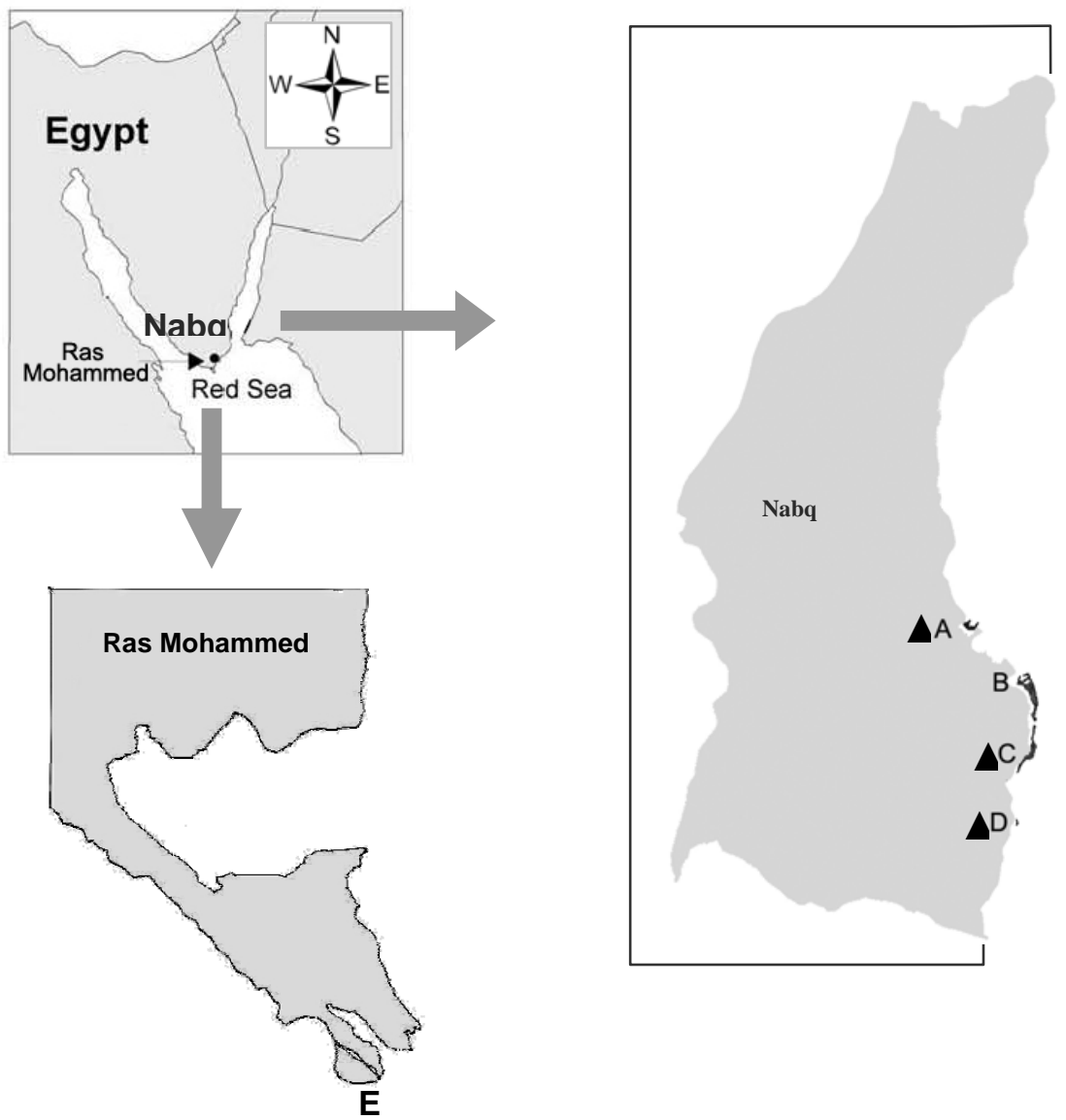

Fig. 1: Mangrove stands in South Sinai:

(A) Monqataa, (B) Rowaiseya, (C) Abu Zabad (D) Gharqana, (E) Ras Mohammed mangrove channel. ( $\mathbf{\Delta})$ seedling distribution study areas. 
Table 1: Mangrove structure parameters of mature trees in different mangrove sites along Gulf of Aqaba during 2006.

\begin{tabular}{|c|c|c|c|c|c|}
\hline \multirow[b]{2}{*}{ Parameter } & \multicolumn{4}{|c|}{ Sampling sites } & \multirow[b]{2}{*}{ Ras Mohammed } \\
\hline & Monqataa & Rowaiseya & Abu Zabad & Gharqana & \\
\hline Stand area (ha) & 13.95 & 53.67 & 28.57 & 0.29 & 2.63 \\
\hline Density (No. stems ha ${ }^{-1}$ ) & 373 & 353 & 216 & 235 & 428 \\
\hline Height range $(\mathrm{m})$ & $(0.5-6.8)$ & $(0.5-7.8)$ & $(0.5-5.5)$ & $(0.5-4)$ & $(0.5-4.5)$ \\
\hline Mean height $\pm \mathrm{SE}$ & $\begin{array}{c}2.63 \\
\pm \\
1.88\end{array}$ & $\begin{array}{c}2.01 \\
\pm \\
1.43\end{array}$ & $\begin{array}{c}1.7 \\
\pm \\
1.31\end{array}$ & $\begin{array}{c}2.164 \\
\pm \\
1.075\end{array}$ & $\begin{array}{c}2.2 \\
\pm \\
1.3\end{array}$ \\
\hline Basal area $\left(\mathrm{m}^{2} \cdot \mathrm{ha}^{-1}\right)$ & 9.2 & 7.9 & 2.8 & 4.8 & 7.3 \\
\hline Canopy coverage $\%$ & 44.74 & 47.11 & 25.25 & 56.93 & 42.62 \\
\hline Diameter at breast height $(\mathrm{cm}) \pm \mathrm{SE}$ & $\begin{array}{c}13.1 \\
\pm \\
2.1\end{array}$ & $\begin{array}{c}12.5 \\
\pm \\
3.4\end{array}$ & $\begin{array}{c}7.6 \\
\pm \\
1.2\end{array}$ & $\begin{array}{c}10.7 \\
\pm \\
2.3\end{array}$ & $\begin{array}{c}10.3 \\
\pm \\
2.9\end{array}$ \\
\hline
\end{tabular}

\section{Grain size analysis and organic matter content}

The major component of the sediment in all mangrove sites is sand, which represents about $90 \%$ in Monqataa and Abu Zabad sites. Other components of sediments are silts and clay, which represent $8 \%$ of grain size (Table 2). There are no main differences between sites in the grain size analysis at top $20 \mathrm{~cm}$ layer.

The total organic matter of soil samples is low in all sites with highest value in Rowaiseya $7.68 \%$ and lowest in Abu Zabad 3.04 \% (Table 2).

Table 2: Soil analysis of different mangrove sites along Gulf of Aqaba, Red Sea.

\begin{tabular}{|c|c|c|c|c|c|}
\hline \multirow[b]{2}{*}{ Sampling site } & \multicolumn{4}{|c|}{ Grain Size (\%) } & \multirow{2}{*}{$\begin{array}{l}\text { Total organic matter } \\
(\%)\end{array}$} \\
\hline & Gravel & Sand & Silt & Clay & \\
\hline Monqataa & 1 & 92 & 2 & 5 & 5 \\
\hline Rowaiseya & 1 & 81 & 7 & 11 & 7.68 \\
\hline Abu Zabad & - & 91 & 5 & 4 & 3.04 \\
\hline Gharqana & - & 85 & 6 & 9 & 4.64 \\
\hline Ras Mohammed & 2 & 79 & 11 & 8 & 3.75 \\
\hline
\end{tabular}

\section{Litterfall}

Total monthly average production of litterfall recorded during 2006 at Rowaiseya site was $169.7 \mathrm{Kg}$. ha ${ }^{-1}$ (SE \pm 23.6). Monthly average litter of leaves was $14.66 \mathrm{Kg}$. ha ${ }^{-1}(\mathrm{SE} \pm 2.53)$, Stem and bark $1.33 \mathrm{Kg}$. ha ${ }^{-1}(\mathrm{SE} \pm 0.2)$, flowers 
$0.35 \mathrm{Kg} . \mathrm{ha}^{-1}(\mathrm{SE} \pm 0.09)$ and fruits $0.61 \mathrm{Kg} . \mathrm{ha}^{-1}(\mathrm{SE} \pm 0.21)$ (Table 3). The highest average weight for the litterfall was during April and the lowest was in January (Fig. 4).

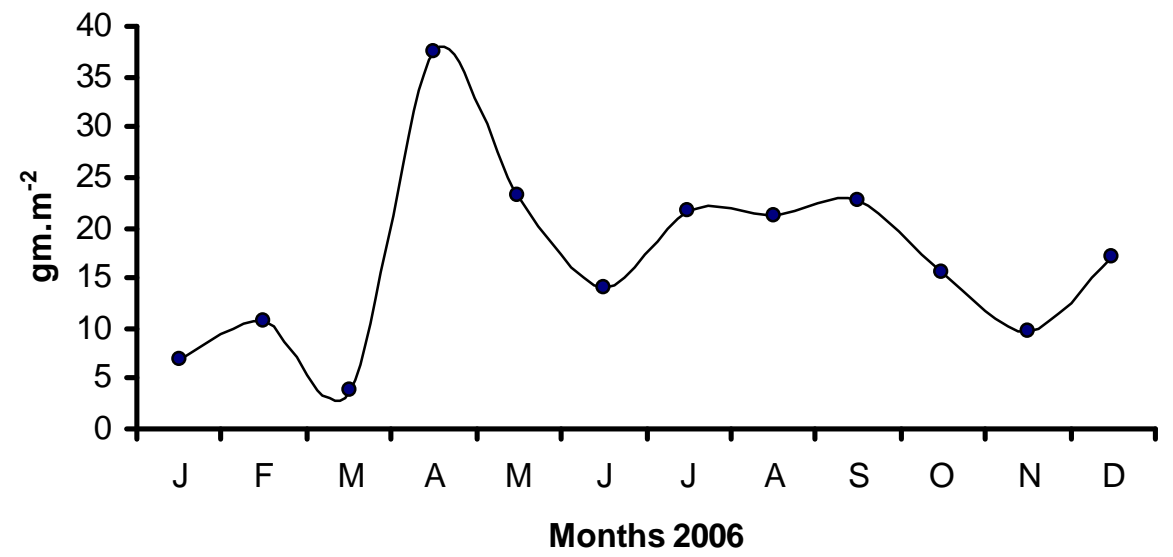

Fig. 4: Monthly mangrove litterfall in Rowaiseya during 2006

Table (3) Monthly average production of litterfall at Rowaiseya during $2006\left(\mathrm{Kg}\right.$. ha $\left.{ }^{-1}\right)$

\begin{tabular}{lccccc}
\hline Parameter & Leaf & Stem and bark & Flowers & Fruit & Total \\
\hline Weight \pm SE & $146.6 \pm 25.3$ & $13.36 \pm 2$ & $3.5 \pm 0.9$ & $6.17 \pm 2.1$ & $169.7 \pm 23.6$ \\
$($ min - max $)$ & $31.5-352.6$ & $7-31$ & $0.1-9.4$ & $0-21$ & $69.4-373.3$ \\
$\begin{array}{c}\text { Peak months } \\
\text { 2006 }\end{array}$ & Apr & Feb & Jul - Aug & May, Sep & Apr \\
Percentage $\%$ & $86.4 \%$ & $7.9 \%$ & $2.1 \%$ & $3.6 \%$ & -- \\
\hline Annual Litter & $2036.7 \mathrm{Kg} \cdot \mathrm{ha}^{-1} \cdot \mathrm{yr}^{-1}=$ & 203.67 & $\mathrm{gm} . \mathrm{m}^{-2} \cdot \mathrm{yr}^{-1}$ & \\
\hline
\end{tabular}

\section{Seedling distribution}

Seedling distribution varied according to measured density; the highest seedling density recorded in Monqataa area was 1848 seedling. ha ${ }^{-1}$, followed by Gharqana (1415 seedling.ha ${ }^{-1}$ ) and lowest values recorded in Abu Zabad (872 seedling.ha ${ }^{-1}$ ).The highest average seedling height was in Abu Zabad $30.7 \mathrm{~cm}$ $(\mathrm{SE} \pm 1)$, and the lowest seedling height was recorded in Monqataa $20.6 \mathrm{~cm}$ ( $\mathrm{SE} \pm 1.2$ ), seedling stem diameter varied between sites with $6.9 \mathrm{~mm}(\mathrm{SE} \pm 0.13)$ in Abu Zabad, $5.4 \mathrm{~mm}(\mathrm{SE} \pm 0.3)$ in Gharqana and the lowest was in Monqataa $4.9 \mathrm{~mm}(\mathrm{SE} \pm 0.2)$. The highest average seedling leaf number recorded in seedling grounds was $7.6(\mathrm{SE} \pm 0.4)$ in Gharqana, while it was about the same at both Monqataa \& Abu Zabad sites (Table 4). 
Table (4) Seedling parameters of Avicennia marina recorded on seedling sites at Nabq protected area during 2006.

\begin{tabular}{lccc}
\hline & \multicolumn{3}{c}{ Sampling sites } \\
\cline { 2 - 4 } Parameter & Gharqana & Abu Zabad & Monqataa \\
\hline Study area (ha) & 5.2 & 6.5 & 5.7 \\
Seedling density (25) $\mathrm{m}^{2}$ & $3.5 \pm 7.2$ & $2.18 \pm 0.3$ & $4.62 \pm 0.3$ \\
Seedling density (No. ha ${ }^{-1}$ ) & 1415 & 872 & 1848 \\
Seedling leaf number & $7.6 \pm 0.4$ & $5.7 \pm 0.23$ & $5.58 \pm 0.29$ \\
Seedling height (cm) & $22.8 \pm 0.95$ & $30.7 \pm 1$ & $20.6 \pm 1.2$ \\
Seedling diameter (mm) & $5.4 \pm 0.3$ & $6.9 \pm 0.13$ & $4.9 \pm 0.2$ \\
\hline
\end{tabular}

\section{DISCUSSION}

Development of South Sinai as tourist area began since 1982. Most of the recreation tourist activities intimately connected with the sea which mainly are diving and snorkeling, bathing activities or some economic and tourist activities e.g. Hotels and mariculture. These activities are creeping to be very near standing on the gate of Nabq Protectorate or even within e.g. Shrimp Farm, the Fishermen Village and the Restaurant and Café of Ghargana. All these activities could affect the marine habitats of the Nabq Protectorate. So, this study is essential and important to describe the ecology of the mangrove habitat which is located on the northern boundaries limits (GEF $1998 \mathrm{a}, \mathrm{b}$ ). These habitats are very important and essential as nursery ground for many marine (Kairo et al., 2001) as well as terrestrial fauna of the area or migratory birds (Balakrishna, 1995). The ecological data of this study is needed for the management and protection of mangrove habitat.

Generally, distribution and extent of the mangrove stands in Egypt are relatively small; they are dispersed along the Egyptian Red Sea coastline in sheltered bays and lagoons protected behind coral reefs. At their latitudinal limits, mangrove communities are generally characterized by decreasing plant height and by patchy distribution (Dodd et al., 1999). Both of these characteristics are apparent in the mangroves of Egypt. As shown from this study A. marina trees heights in Egypt rarely exceed $5 \mathrm{~m}$, reflecting the generally harsh limiting environment (high salinity, low rainfall, unfavorable temperatures) in which they occur.

Results of the present study confirmed that the mangroves of Sinai are similar to the most mangrove stands located in the Arabian region with an average height of $1.7-2.6 \mathrm{~m}$ and total mangrove stands area 99.1 hectares, basal area of $9.2 \mathrm{~m}^{2} \mathrm{ha}^{-1}$ and density up to 428 stems ha-1. In contrast with regional mangrove stands in Oman Avicennia marina mean height of $5.2 \mathrm{~m}$, basal Area of $20.4 \mathrm{~m}^{2} \mathrm{ha}^{-1}$, and density of $650 \mathrm{stems} \mathrm{ha}^{-1}$ (Fouda and Al-Muharrami, 1995). 
Mangrove of Ras Mohammed represents the most dense mangrove vegetation stand within Sinai, with an area of 2.63 ha, due to the limitation in space since Ras Mohammed mangroves grow in a narrow fault line. It is quite possible that the poor reproductive performance of A. marina at Sinai is a result of growth near the distributional limits of the species in the Indo-West Pacific region (Duke, 1990).

Limited productivity data are available for the mangroves of Egypt. However, Galal (1999) has investigated the above-ground biomass and annual litterfall for the mangroves of Nabq, and reported values of $5.4 \mathrm{t}$. ha ${ }^{-1}$ for short trees $\geq 1 \mathrm{~m}$ Avicennia marina communities and up to $74 \mathrm{t}^{\mathrm{ha}} \mathrm{ha}^{-1}$ for tall trees $\geq 4$ $\mathrm{m}$ communities. These above-ground biomass estimates compare readily with other Avicennia marina communities of similar heights in Australia and New Zealand (Saenger and Snedaker, 1993), and suggest that despite the climatic constraints, mangrove standing stock in Egypt is similar to other regions at similar latitudes.

The annual litterfalls for short and tall Avicennia marina communities to be $0.78 \mathrm{t} \mathrm{ha}^{-1} \mathrm{yr}^{-1}$ and $4.82 \mathrm{t} \mathrm{ha}^{-1} \mathrm{yr}^{-1}$, respectively (Galal, 1999). Again, these data compare readily with the annual litterfalls of Avicennia marina communities in other regions, such as Qatar (Hegazy, I998). Annual litterfalls values recorded from Avicennia marina communities north of Jeddah, Saudi Arabia were ranging from 4.41 to $6.53 \mathrm{t} \mathrm{ha}^{-1} \mathrm{yr}^{-1}$ (Saifullah et al.,1989). Estimates were not significantly different to those from Nabq. Given a total mangrove area of $\simeq 525$ ha in Egypt, the annual contribution of mangroves to inshore organic matter is around 1,470 tones, and although not large, this input appears to be significant for inshore productivity.

Results of the present study confirms that seedling density of A. marina (No./ha) in Nabq Protected Area is 1848, 1415 and 872 in Monqataa, Gharqana and Abu Zabad, respectively. Those values recorded in Nabq were lower than considered adequate for natural regeneration. A minimum of 2500 well distributed seedlings per hectare has been proposed (Srivastava and Bal, 1984). Owing to the low seedling density recorded at Nabq and Ras Mohammed protectorates, wild seedling transplantation as well as mangrove nursery establishment may contribute significantly in the restoration of mangrove areas in South Sinai, Egypt. A detailed study of the results of successful plantation field experiment in Nabq Protectorate will be published in another research paper.

\section{REFERENCES}

Balakrishna, P. (1995). Evaluation of intra-specific variability in Avicennia marina, using RAPD markers. Current Science 69 (11): 926-929.

Brady, N. C. (1990). The Nature and Properties of Soils, 10th ed. MacMillan Books, New York, USA, $621 \mathrm{pp}$. 
Dodd, R. S.; Blasco, F.; Rafii, Z. A. and Torquebiau, E. (1999). Mangroves of the United Arab Emirates: ecotypic diversity in cuticular waxes at the bioclimatic extreme. Aquat. Bot., 63:291-304.

Duke, N. C. (1990). Phenological trends with latitude in the mangrove tree Avicennia marina. J. Ecol., 78:113-133.

EL-Gazzar, A. (1995). Egypt: Country Study on Biological Diversity. Publication of National Biodiversity Unit, No. 5, 217 pp. Published in 1993 in Arabic as Publication of National Biodiversity Unit, No. 3.

FAO (2002). Ecological Assessment of Mangroves in Egypt. Consultancy report by Saenger, P. Rehabilitation, Conservation and Sustainable Utilization of Mangroves in Egypt. TCP/EGY/0168. Ministry of Agriculture and Land Reclamation, Ministry of State for Environment, FAO, Egypt, 31 pp.

Fouda, M. M. and Al-Muharrami, M. (1995). An initial assessment of mangrove resources and human activities at Mahout Island, Arabian Sea, Oman. Hydrobiol., 295: 353-362.

Galal, N. (1999). Studies on the Coastal Ecology and Management of the Nabq Protected Area, South Sinai, Egypt. D. Phil Thesis, University of York, York, UK.

GEF (1998a) Egyptian Red Sea Coastal and Marine Resource Management Project. Report 5: Red Sea Coastal and Marine Protected Area Strategy. Part 1: Strategy Development. pp. 50-51.

GEF (1998b) Egyptian Red Sea Coastal and Marine Resource Management Project. Report 5: Red Sea Coastal and Marine Protected Area Strategy. Part 2: Ecosystem Guidance and CMPA Action Plans. pp. 104-111.

Hegazy, A. K. (1998). Perspectives on survival, phenology, litterfall and decomposition, and caloric content of Avicennia marina in Arabian Gulf region. J. Arid Environ., 40: 417-429.

Kairo, J. G.; Dahdouh-Guebas, F.; Bosire, J. and Koedam, N. (2001). Restoration and management of mangrove systems - a lesson for and from the East African region. South African J. Bot. 67: 383-389.

Saenger, P. and S. C. Snedaker (1993). Pantropical trends in mangroves aboveground biomass and annual litterfall. Oecologia, 96: 293-299. 
Saifullah, S. M.; Khafaji, A. K. and Mandura, A. S. (1989). Litter production in a mangrove stand of the Saudi Arabian Red Sea coast. Aquatic Botany, 36: $79-86$.

Semesi, A. K. (1998) Mangrove management and utilization in Eastern Africa. Ambio 27: 620-626.

Snedaker S. C. and Snedaker, J. G. (1984). The Mangrove Ecosystem: Research Methods. UNESCO, UK.

Srivastava, P. B. L. and Bal, H. S. (1984). Composition and distribution pattern of natural regeneration after second thinning in Matang mangrove reserve, Perak Malaysia. In: Proceedings of the Asian Symposium on Mangrove Environment: Research Management. Soepadimo, E., Rao, A.N., Macintosh, D. J. (Eds.), Kuala Lumpar, Malaysia, pp. 761-784. 

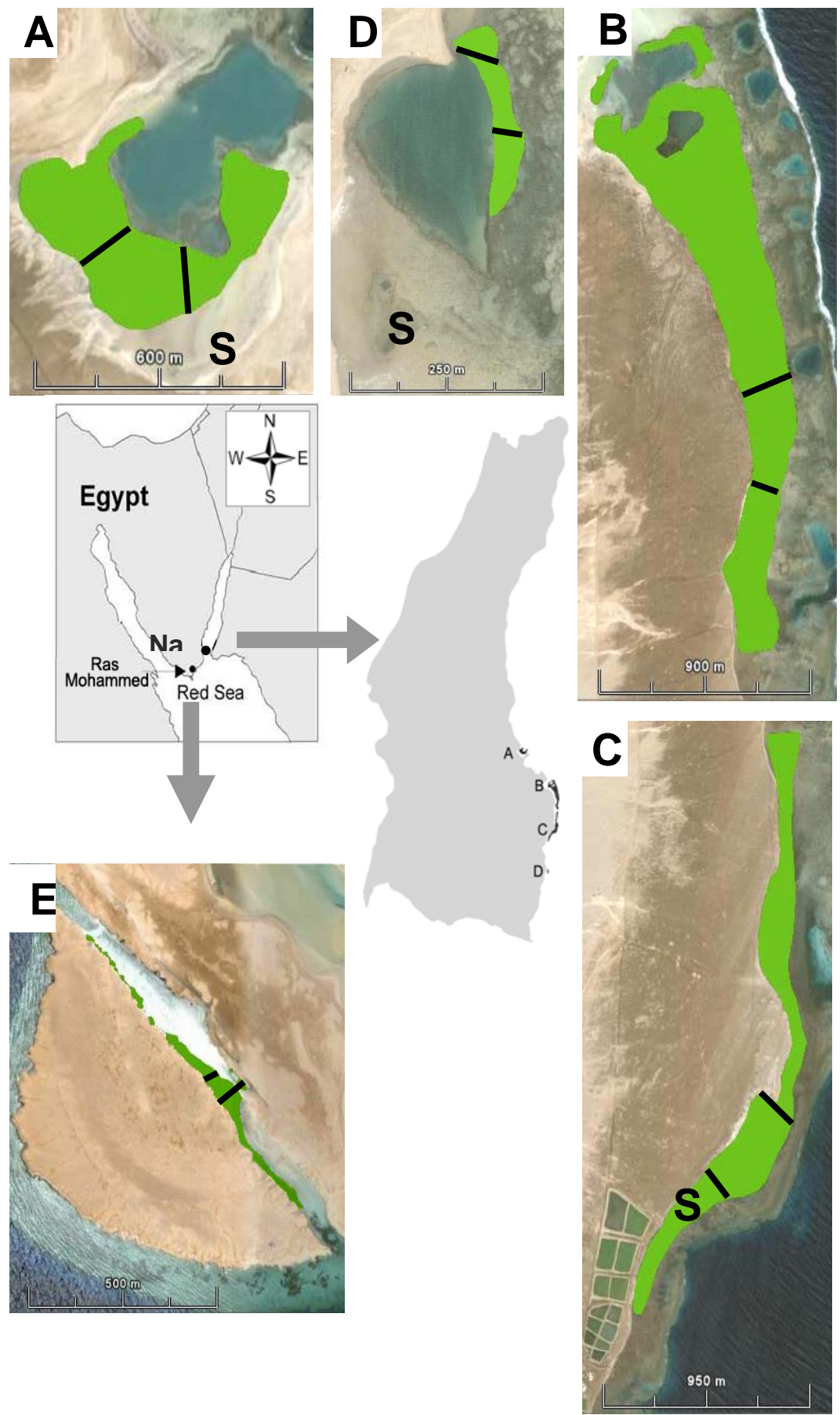

Fig. 2: Mangrove stands in Sinai, black lines represent transect locations in each stand.

(A) Monqataa, (B) Rowaiseya, (C) Abu Zabad

(D) Gharqana, (E) Ras Mohammed Mangrove Channel, (S) seedling areas. 


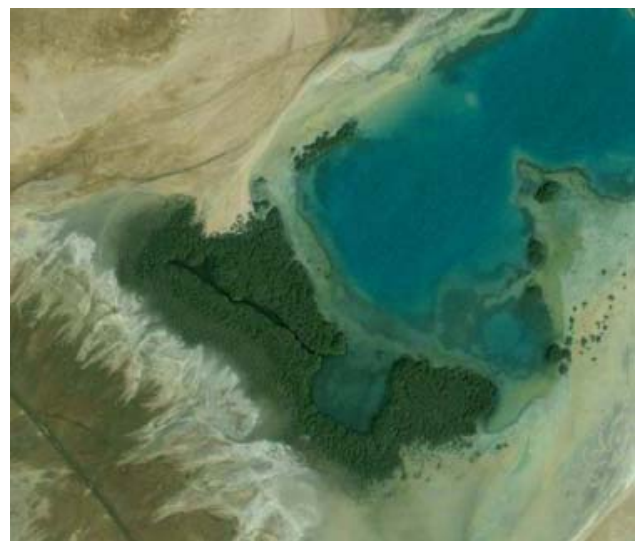

A) Monqataa stand

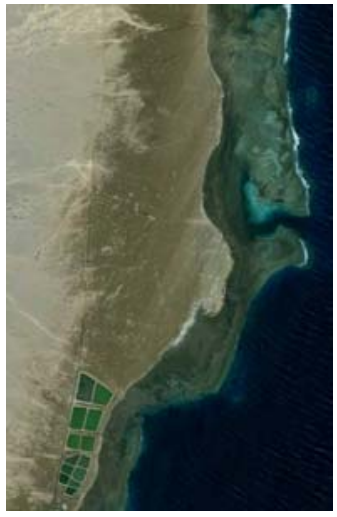

C) Abu Zabad stand

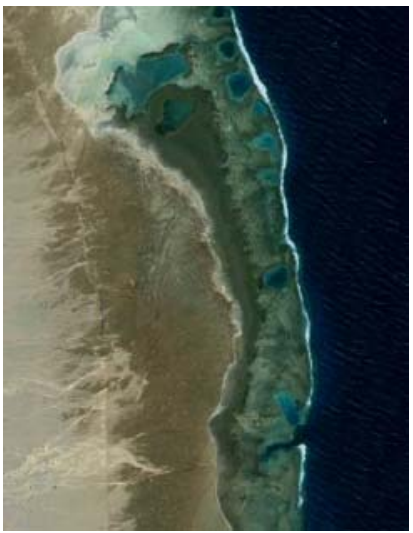

B) Rowaiseya stand

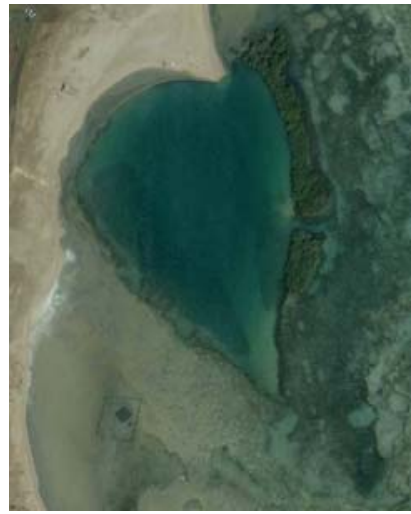

D) Garqana stand

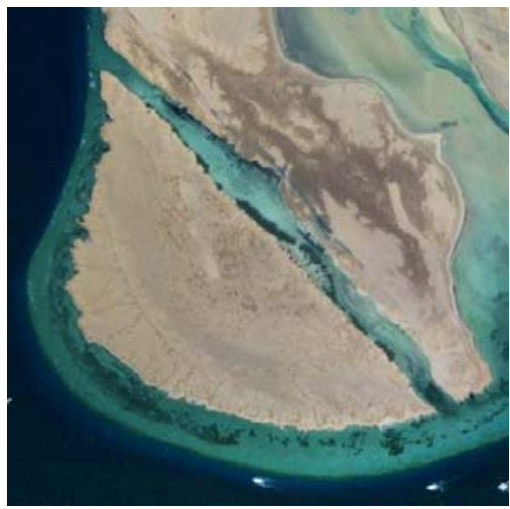

E) Ras Mohammed stand

Fig. 3: Mangrove stands at Nabq and Ras Mohammed protectorates, South Sinai, Red Sea 